\title{
Shifting Cultivation System of Indigenous Moronene as Forest Conservation on Local Wisdom Principles in Indonesia
}

\author{
Rekson Solo Limba ${ }^{1}$, Asrun Lio $^{2}$ \& Yasir Syam Husain ${ }^{3}$ \\ ${ }^{1}$ Department of Sociology, Faculty of Social and Political Science, Halu Oleo University, Kendari, Southeast \\ Sulawesi, Indonesia \\ ${ }^{2}$ Department of English Studies, Faculty of Teacher and Education Science, Halu Oleo University, Kendari, \\ Southeast Sulawesi, Indonesia \\ ${ }^{3}$ Forestry Office, Government of Southeast Sulawesi Province, Kendari, Southeast Sulawesi, Indonesia. \\ Correspondance: Rekson Solo Limba, Department of Sociology, Faculty of Social and Political Science, Halu \\ Oleo University, Kendari, Southeast Sulawesi, Indonesia. Tel: 62-823-4744-7447. E-mail: \\ rekson_unhalu@yahoo.com
}

Received: June 6, $2017 \quad$ Accepted: July 19, $2017 \quad$ Online Published: July 30, 2017

doi:10.5539/jsd.v10n4p121 URL: https://doi.org/10.5539/jsd.v10n4p121

\begin{abstract}
This research is a case study conducted in the village of Indigenous Moronene Huka'ea - La'ea, Watu-Watu village Lantari Jaya sub-district, Bombana. The study followed a series of processes and stages of work in the agriculture system based on local wisdom of Moronene tribe, as one of the patterns of forest conservation. This study applied a "descriptive-qualitative", to describe the social and behavioral conditions of indigenous peoples in managing and utilizing forest resources around the neighborhood where they live. The results of this study indicate that the indigenous of Moronene form of traditional knowledge - local and skills to manage forests for agricultural fields, is quite effective in guaranteeing the sustainability of the forest around the area. One of the local wisdom related to forest management is ancestral policy to regulate the system of grouping the forest area into four zones, including: Inalahipue (rainforest), Inalahi Popalia (sacred forest), Inombo (production forest), and Lueno (forest /wildlife habitat). The practices of shifting cultivation occur in the Inombo forest areas from generation to generations of Moronene in the in the village as the main livelihood systems.
\end{abstract}

Keywords: forest conservation, shifting cultivation system, local wisdom, Indigenous, Moronene, planting, cultural, Indonesia

\section{Introduction}

In response to the destruction of forests in Indonesia, the government has issued two laws as guidelines and instructions regulating the management of natural resources, namely: (1) Law No. 5 of 1990 on conservation of natural resources and ecosystems; (2) Law No. 41 of 1999 on forestry. The conservation law explained that the concept of conservation of natural resources is "a form of resource management and utilization is done wisely to ensure the balance of supply while maintaining and improving the quality and diversity value. Successful implementation of the conservation is highly depending on the degree of public participation and the role of local government. Thus, conservation is the responsibility of the government together with the community, especially indigenous communities around a specific area.

In regard to conservation of natural resources, application of local wisdom of the community is a crucial to be done by each community group, especially in forest areas. There are many local people in Southeast Sulawesi who have local knowledge, particularly in maintaining the forest areas. For example, Nur Arafah (2011) cunducted research on local wisdom of Wangi-Wangi, Wakatobi in forest management of Kaindea, as an adaptation strategy in Kaindea forest management system in a small island. Likewise Wakuasa (2016) examined the local wisdom of ethnic Muna in the context of food security in Muna. There is also a "local wisdom" of Moronene tribe related to the pattern of forest conservation in agricultural field systems as one of the main livelihood of Moronene in Bombana (Limba 2016). As one of the oldest tribes in Southeast Sulawesi, Moronene has a variety of local wisdom in responding to the problems of life, among others in the agriculture field is quite interesting to be studied. Therefore, the author raised the indigenous Moronene issue as the main 
issue of this paper.

Indigenous Moronene, hereinafter in this study abbreviated as MAM, has a variety of local knowledge in agriculture fields. In such wisdom applicability lot of contact with the activities of traditional rituals that demonstrate cultural values that contain customs of local knowledge, and traditional beliefs (trust) that are religious, such as believe in the existence of gods who control the universe, including human life. The belief in the gods was considered to have magical power (supernatural), as one of the cultural dimension of Moronene that regulate the triangular relationship between people, the natural environment, and elements of supernatural powers (supernatural).

Belief in these gods is as expressed by Auguste Comte in his theory of "law of the three stages" (Johnson, 1981) that, on the "theological stage" people believe in many gods that controls the universe. With regard to these beliefs, customs of Moronene believe in the existence of 4 (four) gods called: (1) God of the Land, (2) God of Fire, (3) God of Water, and (4) God of Wind. In their beliefs, the four gods are incarnate form of God, or elements that are considered God by the Moronene in ancient views. In reality of MAM, the four gods have been a source of inspiration of Moronene customary in many aspects of life. For example, the belief in the four gods customarily has spawned a culture of symbolic "count four", namely the phrase "asa, orua, otolu, opaa" or $1,2,3,4$ as a symbol of the power of the gods. Implications of symbolic culture in connection with the forest, is a reference in the grouping of forest areas into four zones as mentioned above, namely: (1) Inalahipue, (2) Inalahi Popalia, (3) Inombo, and (4) Lueno. In its function as a source of inspiration, the four gods are believed to have supernatural powers (supernatural), which dominate and control the universe, including the human life, and thus humans are very docile, obedient, and afraid of the gods. Society does not dare to violate the provisions of the gods. In culture, the beliefs greatly influence the behavior of indigenous peoples and at the same time supporting the implementation of local wisdom in preserving the environment / forest.

The key problem of this study is, "how are the process and implementation stages of the work system of agricultural fields in regard to Moronene tradition". With the subject matter, this study will include a description of rituals to farming, ranging from site selection process which is done by custom, then managed according to the stages of land clearing, planting, crop maintenance to implementation of the harvest and a harvest festival by end of the year as a ritual greeting farmers thanks to the giver of fortune that transformed by Sang Dewi Sri called "Sangkoleompae". The aims is analysing and explaining the process and stages of working at agricultural field of MAM at Kampung Huka'ea - La'ea.

\section{Literature Review}

\subsection{Cultural Theory}

In the theory of culture, Koentjaraningrat (2000: 1) states that there are two groups of views on the concept of culture, (1) lay groups, defining the culture is the whole totality of the mind, the work and the work of human beings who are not rooted in the instincts, but only triggered after going through a learning process; (2) a group of experts, to understand culture through the 7 seven elements, namely: (a) the system of religion and religious ceremonies; (b) system and community organizations; (c) knowledge systems; (d) the language system; (e) the system of art; (F) livelihood systems; and (g) technology and equipment system (Koentjaraningrat, 2000:2). He further explained that culture can be seen in at least three states, namely: (1) the form of culture (abstract), in the form of ideas, values, norms, regulations and so on; (2) the form of culture as social systems, namely all forms of society behavior patterns, such as ways to interact, relate and get along with each other; and (3) cultural manifestation (physical), human's work which can be touched or seen. As Tylor said about culture is, the whole complex in knowledge, belief, art, morals, law, customs, and other abilities that a person earns the learning process in the community, such as traditional knowledge systems - local, is as one of the forms of culture (Liliweri, 2014: 4).

Furthermore, one of cultural theories of from Kluchkohn (cited in Koentjaranigrat, 2000: 29-31), explained that culture from the essence of the culture of relationship between human and nature and the essence of the relationship between human and other people. On that theory, Kluchkohn reveals that the essence of relationship between human and nature in human consciousness which considers that "nature is powerful", because human in general can only give up without a lot of effort that can be done to strugle it, therefore, human has always tried to maintain the balance of the world. Otherwise, there is also a culture view that considers nature is something that can be fought by human, and therefore man is always trying to change and conquer the nature (Koentjaranigrat, 2000: 29-31). The implication of this theory that is that people who have local knowledge and traditional knowledge systems about nature, will not dare to destroy the nature, especially forests. 


\subsection{Religious Theory}

Religious theory explains that human believes in "the existence of sacred", it is beyond the capacity and power, therefore human should ask for its protection by maintaining the natural balance through various ceremonies. In relation to the universe and the environment, a local wisdom derived from traditional knowledge systems, which serve as guidelines to behave for a primitive society; it is essentially influenced by the belief system (animism) about the existence of supernatural powers.

Koentjaraningrat classifies the origin of religion into three groups, namely: (a) theories that orient to religious beliefs (b) theories that orient to the human attitude towards the supernatural or the occult and (c) the theories that orient in its approach to the religious ceremony. These three theories are described briefly as follows:

1) Theory of religious belief states there is a supernatural ability to work strongly in the human soul that can lead to weaken the activity of the human mind.

2) Theory of human attitude toward its invisibility; according to the religious system, belief and religion in the world centered on a concept of unseen things (mysterium) that are considered almighty (tremendum) and the sacred.

3) Theory of religious ceremonies; the basic principle of this theory is approaching the problem in a different way called bersaji (serving) ceremony. Smith considers that the bersaji ceremony is an activity to encourage a sense of solidarity with the gods (source: http//mr-rifaifajrin.blogspot.co.id.).

According to Kruyt, (1906) in (Rambe, 2002: 155), human primitive generally convince the existence of a subtle substance called zielestof, namely the one who gives life and motion to force a lot of things in the universe. In another view, Tylor (1873) explains that animism is a belief in the existence of spirits and the spirits that inhabit the whole universe. This theory is a forerunner to the emergence of human consciousness would be their soul and spirit (Hadiwijono, 1985: 9). In another source, it is a system of human behavior to obtain something he wants, he performs the ritual surrender himself to the creator (Source: http://teoriantropologi.blogspot.co.id).

\subsection{The Local Wisdom Theory}

The local wisdom theory has long been perceived benefits for the life of the human being. Since the ancient Greece, when the law, the courts, and lawyers do not yet exist, then "wisdom and discernment" are the only tools that can be used by a leader to set order of people's lives at that time (Sibarani, 2012:109). To understand the notions of local wisdom, it needs to put forward some definitions as follows.

According to Quaritch Wales (1949); the term of "local wisdom", means as "the ability of local culture are facing the inluences of foreign cultural, when the two cultures are related" (Rosidi, 2011:29); Mariane, 2014:111). Keraf (2002:289) affirms that local wisdom is all forms of knowledge, beliefs, comprehension or knowledge, as well as custom, or ethics of human behaviour in the ecological community's lives. Furthermore, Sibarani (2012:113) suggests the concept of "local wisdom" in two perspectives, namely from culture value and wisdom perspectives. The cultural value sees local wisdom as the aplication of local culture values, while custom perspective utilizes set order of society as a wise. In this sense, the local wisdom is a regulation/custom value based on customary law and cultural traditions that became guidelines in regulating the order of people's lives.

It is explained in the concept of "oral tradition" that the concept local wisdom can be understood from three perspectives, namely: (1) the structural perspective, (2) cultural, and (3) functional. Firstly, the structural perspective views local wisdom as the uniqueness of the social structure developed in the environmental community. Secondly, cultural perspective considers local wisdom as the value created, developed and maintained by society itself. Thirdly, the functional perspective sees the local wisdom as community's ability to play roles and functions (Sibarani, 2012:117). While others, Mariane, (2014:114) affirms that local wisdom is all values in a society that is believed to be the truth so that it becomes a policy reference to behave in local communities'. The trust influences the behaviour and actions of human beings towards the natural environment become very sensitive and cautious, especially in managing and utilizing forest (conservation), so that the forests remain sustainable. Thus, the treatment of such wise and sensible must be created in order to foster a collective consciousness to the society for not destroying forests, do not violate the customs and the natural resources, especially forests as area/ acreage that will be utilized for human purposes.

\section{Theoritical Model}

\subsection{Traditional Knowledge System}

According to Haryati Soebadio (cited in Ayatrohaedi, 1986:18); the concept of "local wisdom", or also referred 
to the concept "local geniuss" means cultural identity, or identity/ personality of the nation approppriate the character and capabilities of its own with the result that led the nation able to absorb and cultivate foreign culture. While according to Moendardjito, the local genius is derived from local knowledge of regional culture element, because the culture in each area potentially become local genius, with requirements, tasted its ability to survive until now (Mariane, 2014:112).

Indigenous knowledge is any form of knowledge and behavior of local communities that have been practiced by human in their interaction with the natural environment. Local knowledge was relied upon decision making at the local in everyday life. For example, in hunting, fishing, gathering food from forest products, agriculture and animal husbandry, food production, water and health, and how to adapt on environmental change and social change (Sibarani,2012;120). Indigenous knowledge has a uniqueness, where the blessed transformation system, which only passed down through oral tradition ways such as in terms of cultural values, skills, behavior, and other properties, but can be recorded and stored in the human memory.

\subsection{Concept of Natural Resource Conservation}

Essentially, natural resource is source of human life, therefore human is very depending on the natural resource. The concept of natural resource consists of either renewable natural resources or converse of non renewable natural resources. In this Study, the concept of natural resource conservation refers to Law No. 5 of 1990, which regulates all kind of natural resource conservation and management to guarantee the balance supply by protecting and increasing the quality of diversity and its value. While the concept of forest as in law no. 41 in 1999 , article 1 paragraph 2, affirms that forest is "a unity ecosystem of land containing natural resources which dominated by plant trees in its natural forms that cannot be separated from one environment and another.

\subsection{Shifting Cultivation System}

Etymologically, Shifting cultivation system can be explained from two aspects, namely from the aspect of livelihood and of the way its work. Firstly, shifting cultivation is the oldest system in the world which has already existed since 6000 or 7000 years BC (Spencer, 1966; Fox, 2000). The system applies a rotation model which is called 'shifting cultivation' or slash and burn agriculture, and or by the term of swiden agriculture (Koentjaraningrat, 1985: 41). Secondly, from the aspect of land use and how it works, the shifting cultivation system which cultivates land forest by clearing and burning in the dry season, then cleaned and nourished back. After that, the lands are planted by agricultural crops. The forests will not cause permanent damage as caused by other forest harvesting system.

After the use of 1 to 3 harvest seasons, the field is rested to uncultivated for recovery (source: http://krizi.wordpress.com). The land recovery system is called "rotation". In general, the fallow period lasts for 7-10 years. But the longer the fallow period is the better to achieve the quality of soil fertility is concerned. Based on the relevant literature review and theories as described in the previous chapter, to explain the research problem, it will be described the following framework.

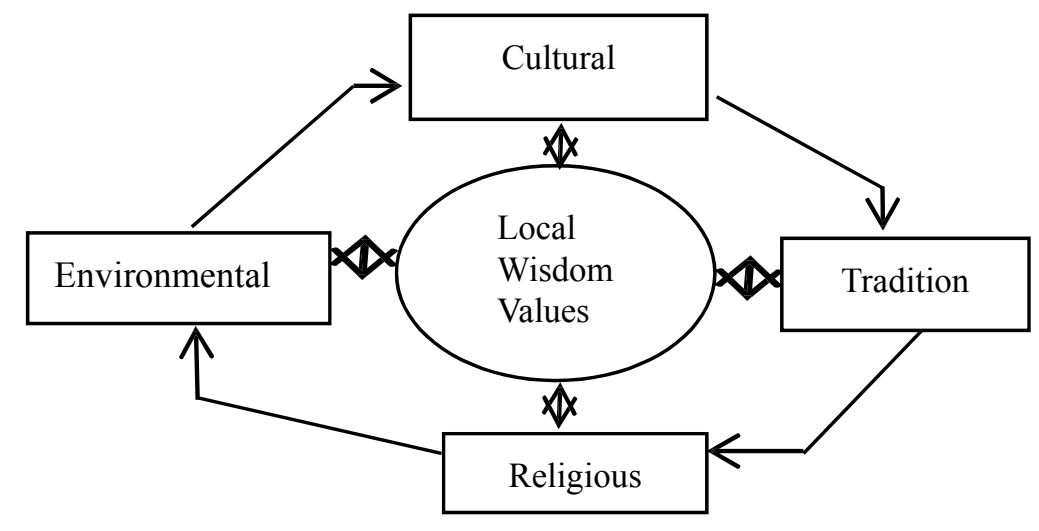

Figure 1. Framework

Source: Framework adapted from Limba'soctoral thesis, 2016

As the definition of local wisdom mentioned above, that essentially, local wisdom is the overall values prevailing in society as a local wisdom that should be implemented (Mariane, 2014: 114). The process of "local knowledge" formation of MAM, particularly those related to the shifting cultivation systems, essentially is a series process that begins from the application of the culture values that generates traditional knowledge systems 
in the form of customs and procedures of the management/utilization of natural resources and others. The application of traditional knowledge system carried out carefully in accordance with the customs of ancestors whom believed have control of spirits as an incarnation of god.

As the heritage, the obedience and adherence of MAM toward customary create a religious system that leads human to believe in god. In order MAM live in peacefully, tranquility and friendly to nature, religious system encourages human to be able to adjust or adapt to both the physical environment and to the supernatural. The series of these processes have encouraged the growth of collective consciousness for MAM to make local wisdom as a guide in addressing and resolving social problems, either in social life or in treating the natural environment around them.

In Moronene culture, ancestors who embrace animism have bequeathed to future generations until now, they are there believe in in the 4 (four) major gods as embodiments symbol "divinity" that regulate and control the universe: (1) the god of land, called Sangia Tumondete; (2) the god of fire, called Sangia Mponga'e; (3) The god of wind, called Sangia Laamoa; and (4) the god of water, called, Sangia Olaro (Interviewed: Mansur Lababa, 55 years old, Chief of Indigenous Moronene Totongano Wonua Huka'ea - La'ea on January 15, 2016).

Believe in the four the gods is a source of inspiration for MAM and the implications on local wisdom, especially in grouping the forest area into 4 (four) regions with their respective functions as follows:

1) Inalahipue; is the forest core (primary) in the mountainous area that serves as supporting forest life support ecosystems in downstream. The forest becomes a protected forest.

2) Inalahi Popalia; is the primary forest that has various places hallowed by the local people, because the status of the forest is forbidden forest that cannot be used / treated by residents.

3) Inombo; is the forest designated by the chairman of Indigenous Moronene, Adati Totongano Wonua, as it is determined as production forest area which can be used by residents, either as land farming / plantation, settlement or for development activities in the public interest.

4) Lueno; is the forest which consists of savannah desert (reeds), and partly groups of small forest (Olobu), and mangrove forests on the coastal area.

\section{Research Methodology}

This research is a case study on local wisdom of MAM associated with patterns of forest conservation in the shifting cultivation system use "descriptive-qualitative" approach. This approach was applied to describe the social and behavioral conditions of indigenous people in managing and utilizing forest resources in the area where they live. This research was conducted in Kampung Adat Moronene, Huka'ea - La'ea in Taman Nasional Rawa Aopa Watumohai (TNRAW) Southeast Sulawesi. It was determined as a research location due to some reasons: (1) the location is accessable, (2) the research materials are available in the area; (3) The population are native tribes of Moronene; (4) the main livelihood is shifting cultivation which based on local wisdom; (5) as an indigenous village; (6) The local people have established the indigenous institution, called Lembaga Adat Moronene Totongano Wonua, Huka'ea - La'ea.

This study applied emic method as one of strategies to get the data that really original from the informant point of view (the subjects of the study). In this regard, the researcher gave the chance and the opportunity freely to the informant to deliver all data and information related to the research problem, according to their perspectives and experiences. In this sense, the researcher is not based on the principle of what is supposed to happen, or "what people think" by researcher (dassain), but based on "what in natural fact" in the field (dassolen), which is the information about informants' narratives. All data and information are discussed in an open forum through Focus Group Discussion (FGD) or focus groups, which presents a group of stakeholders with a qualitative approach requires a fully information/data. To ensure consistency / conversation to keep it out of the context of the research, it can be controlled by a researcher through "ethics method", in which the researcher views about something related to the cases studied.

The instrument or tool of this research is human (Moleong, 1984), in this sense, "the researcher himself" and research assistants who were recruited for the field research that preceded the discussion about the direction of research to be done. In addition to the human instrument, some equipment such as; digital camera, recorder, diary and others are used for data collection to record the verbal information, photograph and relevant events occurred in the study field site. This approach will allow the research data at any time can be changed / adjusted to the development of empirical data observed.

This study involved involves two elements in the community: (1) MAM in Kampung Huka'ea-La'ea, namely the 
farmers in the fields. In addition, farmers of Moronene who resided outside Kampung Huka'ea-La'ea, who recognized the traditions and customs of Moronene regarding to the utilization of forest resources. (2) External informants such as element of government of Bombana and element of social institutions that related to research topics, such as NGOs and academia.

\section{Results and Discussions}

The implementation of the shifting cultivation system in Huka'ea-La'ea village, Watu-Watu village, Lantari Jaya sub-district, Bombana district can be explained into 11 stages as follows:

\section{1) Mo'onto Wita (selection of cultivation area)}

The first stage is to find / select locations on Inombo forest areas for cultivating. Inombo forest is customary land used specifically as productive area. In this forest area, the farmers under the leadership of the group will take sample soil, hereinafter "predicted" (dikilala) to determine the nature and character of the forest area, suitable or not to be used as cultivation areas for farmers in the future.

\section{2) Umowu (cutting small trees, roots and mow)}

The Kilala ritual indicates a good indication, so the farmers will calculate a good time to do the next phase, namely "umowu". This activity is the stage of cleansing the root shrub, small trees and weeds that grow under a large tree. On this stage, the large trees called 'monea' are easy to be cut. This activity can be done by group of farmer, both adult women and men in mutual cooperation (called meliuha).

\section{3) Monea (cutting huge trees)}

After umowu, the following event is monea activity. This activity includes the hardest stage in the shifting cultivation system where the huge trees are cut down, only using simple equipment, namely, axes, machetes and a whetstone. Monea is carried out in mutual cooperation (meliuha), by male group of farmer.

\section{4) Humuni (burning stage)}

After felling trees (monea) stage, the next activity is humuni meaning phase of burning. This activity should wait until the dried process and felled results by the heat of the sun for a \pm 1.5 , up to two months. To ensure the security during combustion (bruning), then every farmer doing mekere/ meheasi; cleansing of twigs, dried leaves on the boundary area around the fields so the fire did not spread out the area at the time of burning.

\section{5) Modahai, wungkali dan montunu inoto.}

The term modahai, wungkali, and montunu inoto are a series of activities carried out after the mass burning. Branches of wood are cut, designed, stacked at some place called inoto, and then burned to clean, so the area is declared ready for planting and then burned.

\section{6) Mewala (making fences of cultivation field)}

While waiting for the planting season arrives, farmers do fencing around the fields called mewala. Mewala means "make the fence" to secure the acreage field crops in the fields of pests, (wild animals like wild boar, elk / deer) and others.

\section{7) Planting Stages}

In the shifting cultivation systems of MAM, there are two stages of planting, namely: planting of corn or mombula puhu conducted prior to motasu (sowing) stage. In general, motasu activity (planting upland rice) made 15 days after planting the corn. Both of these activities carried out after clearing the land or ready for planting, and fencing around the cultivated fields respectively. Planting activities, both corn and upland rice is done by men and women with a system of mutual assistance rotation (meliuha). To get a lot of results, then the seed corn or rice should be taken from excellent quality. The division of labor in motasu stage consists of two groups: a group of men are in front position to make a hole, then followed a group of women behind to sow the seeds / seedlings. The tools used are pointed round wooden stick on one end called "potasu". To make the stick sharp and durable, the end of the stick should be dried by the fire. The place of seed is called balase mpowuwuiha, it is a kind of bags made of woven leaves agel (palm). These containers filled with rice seed of \pm 1 liter and hold by each group of farmer. When the seed is finished, then the container is filled again with seed.

\section{8) Morobusi (weeding)}

Morobusi activity is a weeding time for rice and corn plants of grass and weeds as a major nuisance plant growth and fertility. This activity also usually done by meliuha (mutual assistance), but usually, more often done by the owner of the field along with his family members. 


\section{9) Montoria (keeping birds away)}

The term montoria is one step ahead of the activities during harvest season. Montoria means to preserve and maintain the crops. The montoria is a very hard job because the person incharge should control and spend spends the nignt for preserving the plant. One way to help make nightly guard is by fencing around the field and should be powerful and tidy, so that the wild pigs cannot enter in the field.

\section{0) Mongkotu (cutting rice)}

The term "mongkotu" also called "mosowi", which means cutting the upland rice fields. The tool used to cut the rice called "ani-ani" sometime called 'pongkotu', it is a short little knife made specifically for cutting rice in the fields (see picture below). Mongkotu activity during the harvest season is the most important phases for farmers. In the harvest season, the owners of the field rejoice prepare a variety of needs to welcome the harvest season. During the harvest season, farmers go to the fields to harvest rice every day, and at night they gather in one place to fry rice dryly (mohole) and ground into a "new rice" to be consumed by the family, because eating "old rice" is prohibited (taboo) during the harvest season.

\section{1) Mewuwusoi (harvest ritual at end of the year)}

The term "mewuwusoi" is a ritual performed by a group of farmer communities led by Tompuroo, at the end of the rice harvest season. It is because mewuwusoi means "harvest festival by the end of the year." The philosophy of mewuwusoi ritual, the party held joy by all members of the family farmers in a community Tompuroo (shaman rice). This activity commonly carried out at the home of Tompuroo, but can also be implemented in another house by agreement. In Moronene farming culture, ritual end of the year "mewuwusoi" essentially contains four meaning of philosophy, namely;

a) An expression of gratitude to God as the fortune giver, in this case is as Sangkoleompae;

b) An expression of gratitude to Sangkoleompae who has been willing to live in the world to serve farmers throughout the year of harvest;

c) To let go the harvest year and accompanied the departure of Sangkoleompae back to heaven;

d) To feed to the public, as an expression of sharing with others over the fortune given from God.

Besides the four meanings, mewuwusoi is also a symbolic meaning as the "split - welcome" called "mododo" and "modepe". Mododo means pounding rice in a mortar together, usually four people. Mododo implies ritual to release years and accompanied the departure of Sangkoleompae back to heaven. While modepe means hitting around mortar body with round bamboo in the end of it split apart in order to create sound when struck on the body of the mortar. This is done by some people as a ritual to call Sangkoleompae to come back again in next harvest season.

\section{Conclusion}

The implementation of local wisdom values in forest conservation; principally local values can be used as an effective way to find solutions of various problems that arise in society, including the customary law. In the ancient, before court and modern law system exist, such a local wisdom is applied by community to wisely manage the community's social order (Sibarani, 2012:109).

Besides, the local wisdom is also arranged through the orders which have been decided by Lembaga Adat Moronene Totongano Wonua (customary institution of Morenene) Huka'ea La'ea. It is about the efforts to save the forest. In the structure of customary institution, it has been organized the division of obliation and responsibility in the implementation of of local wisdom values in natural resource management. It is divided into four divisions: (1) Totongano Inalahi (forest issue); (2) Totongano Lombo (agricultural issue); (3) Totongano Kadadi (wildlife issue); dan (4) Pembue'a (health/traditional issue).

It is found that the local wisdom of MMA in the utilization of forest in Huka'eaLa'ea, both shifting cultivation farmers and the gatherers of forest product cannot be separated from forest because forest is their main livelihood. With the local wisdom, MMA has interest on both utilizing and protecting the forest and it can be passed from generation to generation. One of the local wisdoms of Lembaga Adat Totongano Wonua is the obligation of the inhabitant to replant trees after they are cut, such as: rattan, pitch tree, and cordwood have to be replanted with the same plant or other seed such as silk tree, mahogany, acacia, etc.

\section{References}

Akhmar, A. M., \& Sarifuddin. (2007). Mengungkap Kearifan Lingkungan Sulawesi Selatan (Revealing local wisdom of enviorenment in South Sulawesi). Pusat Pengelolaan Lingkungan Hidup Regional Sulawesi, 
Maluku dan Papua, Kementrian Negara Lingkungan Hidup RI, dan Masagena Press

Akullo, D. (2007). Indigenous Knowledge in Agriculture : A Case Study of The Challenges in Sharing Knowledge of Past Generation in Globalized Context in Uganda. Paper of World Library in Information Congress Durban. South Africa.

Arkanudin. (2012). Sistem Perladangan dan Kearifan Tradisional Orang Dayak Dalam Mengelola Sumber daya Hutan (Shifting cultivation system of Dayak in forest resource management). Retrieved from http://www.academia.edu.com

Basuni, S. (2012). Mengelola Konservasi Sumber Daya Alam Hayati Berditionalbasis Pengetahuan Tradisional dan Kearifan Lokal (Natural resource management in relation to traditional knowledge and local wisdom), Paper presented at Hotel Senyiur. Balik papan - Kalimatan Timur.

Brusce Mitchell, DKK. (2010). Pengelolaan sumber daya dan Lingkungan (Natural resource and enviorenmental management). Gadjah Mada University Press, Cetakan IV.

Bungin, B. (2006). Metodologi Penelitian Kualitatif Aktualisasi Metodologis ke Arah Ragam Varian Kontemporer (Qualitative reaserch methodology, contemporer variant). PT. Raja Grafindo Persada. Jakarta.

Creswell, J. W. (2013). Research Design, Pendekatan Kualitatif, Kuantitatif, dan Mixed. (Translated by Ahmad Fawaid) Pustaka Pelajar. Yogyakarta.

Fauzi, H. (2012). Sistem Perladangan di Indonesia: Suatu Studi Kasus dari Kalimantan Barat (Shifting cultivation: a case study in West Kalimanan). Gadjah Mada University Press. Yogyakarta.

Hawley, A. H. (1950). Human Ecology A Theory Of Community Structure. The Ronald Press Company New Yor (Fauzi 2012:63).

Keraf, S. (2002). Etika Lingkungan (Enviorenmental ethic). Jakarta. PT Kompas Media Nusantara.

Mariane, I. (2014). Kearifan Lokal Pengelolaan Hutan Adat (Local wisdom in customary forestry management). PT. Raja Grapindo Persada, Jakarta.

Moleong, L. J. (1994). Metodologi Penelitian Kualitatif (Qualitative research methodology). PT. Remaja Rosda Karya, Bandung.

Mukhtar, dkk. (2010) Pengelolaan Program Hutan Kemasyarakatan Berbasis Kearifan Lokal: Studi Kasus di Kawasan Hutan Lindung Sesaot Lombok Barat (Community forest program: a case study in pretected forest of Sesaot, Lombok Barat). Wacana, 13(1).

Nababan, A. (2010). Wiratno et al. (2002). Kearifan Masyarakat dalam Pengelolaan Lingkungan di Indonesia di Masa Mendatang (Local wisdom in enviorenmental management of Indonesia in the future). Retrieved from http://www.amanor.id

Nugraha, A. (2005). Rindu Ladang, Perspektif Perubahan Masyarakat Desa Hutan (Yearning of agricultural field, transformation perspective of people in the forest village). Wana Aksara, Banten - Indonesia.

Nur, A. (2011). Kaindea: Adaptasi Masyarakat dalam Pengelolaan Hutan di Pulau Wangi-Wangi, Kabupaten Wakatobi. Disertasi, Universitas Padjadjaran, Bandung.

Nurrochmat, D. R. (2005). Strategi Pengelolaan Hutan, Upaya Menyelamatkan Rimba Yang Tersisa (Forest management strategy, an effort of forest safety). Pustaka Belajar.

Rambe. (2002) Kebudayaan Moronene: Berbagai Ritual Sekitar Mata Pencahariannya Hidupnya, Tinjauan Gepgrafis, Historis dan Antropologis (The culture of Moronene: various ritual on people's livelihood, geographyc, history and anthropology).

Rosidi, A. (2011). Kearifan Lokal dalam Perspektif Budaya Sunda (Local wisdom in Sundanese culture). PT Kiblat Buku Utama.

Spencer. (1966). Shifting Cultivation in Southeastern Asia. University of California Press, Berkley \& Los Angeles, USA.

Spradley, J. P. (1997). Metode Etnografi (Ethnographical method). Yogyakarta, Tiara Wacana.

Storm, Br. G. (1925). Naskah Tanam Padi oleh To Moronene di Rumbia (Planting rice of Moronene in Rumbia). KILTV, Leiden.

Subadi. (2010). Penguasaan dan Penggunaan Tanah Kawasan Hutan, Menuju Penguasaan dan Pendayagunaan Berwawasan Lingkungan, Berkelanjutan dan Berpihak Pada Kemakmuran Rakyat Dalam Perspektif 
Otonomi Daerah (Controlling and the use of forest area in enviorenmental perspective for suistanability and people prosperity in the regional autonomy). PT. Prestasi Pustakaraya, Jakarta. Indonesia.

Suharjito, D., \& Putro, H. R. (2013). Pembangunan Kehutanan Indonesia Baru Refleksi dan Inovasi pemikiran (Forest development in Indonesia, a new inovation and reflection). PT. IPB Press, Kampus IPB Taman Kencana Bogor, Cetakan Pertama: Desember 2013.

Ukur, F. (1994). Makna Religi dari Alam Sekitar Dalam kebudayaan Dayak (Religious meaning of nature in Dayak culture). Editor: Paulus Florus ed., Grasindo, Jakarta.

Zain, S. (1998). Berkaca di Cermin Retak: Refleksi Konservasi dan Implikasi Bagi Pengelolaan Taman Nasional (Reflecting on Cracked Mirror: Reflections on Implications for Conservation and Management of National Parks). Jakarta.

\section{Copyrights}

Copyright for this article is retained by the author(s), with first publication rights granted to the journal.

This is an open-access article distributed under the terms and conditions of the Creative Commons Attribution license (http://creativecommons.org/licenses/by/4.0/). 